\title{
A Bibliometric Analysis of Public Relations Models
}

\section{Halkla İlişkiler Modellerinin Bibliyometrik Analizi}

\author{
Zuhal GÖK DEMIR $^{1 \oplus}$, Fulya ERENDAĞ SÜMER ${ }^{2}{ }^{\oplus}$, Çiğdem KARAKAYA ${ }^{2}$
}

'Asst. Prof. Dr., Akdeniz University, Faculty of Communication, Department of Public Relations and Advertising, Antalya, Turkey ${ }^{2}$ Assoc. Prof. Dr., Akdeniz University, Faculty of Communication, Department of Public Relations and Advertising, Antalya, Turkey

ORCID: Z. G. D. 0000-0001-6489-3125; F. E. S. 0000-0002-5655-4542;

Ç. K. 0000-0002-1172-0973

\section{Sorumlu yazar/Corresponding author:}

Zuhal Gök Demir,

Akdeniz Üniversitesi, İletişim Fakültesi, Halkla İlișkiler ve Tanıtım Bölümü, Antalya, Türkiye

E-posta/E-mail:zuhalgokdemir@akdeniz.edu.tr

Geliş tarihi/Received: 28.01.2020 Revizyon talebi/Revision Requested: 21.02.2020

Son revizyon teslimi/Last revision

received: 02.06 .2020

Kabul tarihi/Accepted: 12.06.2020

Online yayın/Online published: 17.07.2020

Atıf/Citation: Gök Demir, Z., Erendağ Sümer F., \& Karakaya, Ç. (2020). A bibliometric analysis of public relations models. Connectist: Istanbul University Journal of Communication Sciences, 58, 105-132. https://doi.org/10.26650/CONNECTIST2020-0015

\begin{abstract}
The aim of the study is to reveal the trends in the field of public relations by examining the topic of 'public relations models' in order to capture the variation in public relations practice. Bibliometric analysis has been chosen as the methodology in this study to show publishing patterns as it finds out the stream of knowledge and the development of literature in a specific discipline. Data used in this research were collected from Thomson Reuters Web of Science Database. By selecting the topic of 'public relations model' in the search button, 595 studies were investigated within the context of institution and country collaboration, cocitation network analysis, co-word network analysis and citation burst. In order to perform these network analyses, the CiteSpace II software package has been used. The findings suggest that the USA as a country, universities in the USA as institutions and academics from the USA as author collaboration are found to be the top ranked items by centrality on the topic of public relations models. Grunig and Grunig's (2002) paper on public relations and communication models is found to have the strongest citation burst as expected. The most investigated research topics are global flux, the blog-mediated crisis communication model, and stakeholder relationship.
\end{abstract}

Keywords: Public relations, public relations models, Grunig, bibliometric analysis, CiteSpace II

Öz

Bu çalışmanın amacı, halkla ilişkiler alanındaki değişimi göstermek amacıyla 'halkla ilişkiler modelleri' konusunu inceleyerek halkla ilişkiler alanındaki eğilimleri ortaya koymaktır. Bu çalışmada yayın örüntülerini göstermek için, belirli bir disiplinde bilgi akışını ve literatürün gelişimini ortaya koyan bibliometrik analiz, metodoloji olarak seçilmiştir. Bu araştırmada kullanılan veriler Thomson Reuters Web of Science Veritabanından toplanmıştır. Bu bağlamda, arama motoruna 
'halkla ilişkiler modeli' kavramı yazılarak, kurum ve ülke işbirliği, ortak atıf ağ analizi, ortak kelime ağ analizi ve atıf patlaması bağlamında 595 çalışma incelenmiştir. Bu ağ analizini gerçekleştirmek için Citespace II yazılım paketi kullanılmıştır. Araştırma bulgularına göre ülke olarak $A B D$, kurum olarak ABD'deki üniversiteler ve yazar işbirliği olarak ABD'den akademisyenler halkla ilişkiler modelleri konusunda merkeziyete göre en üst sırada yer almaktadır.
Beklenildiği üzere Grunig ve Grunig'in (2002) halkla ilişkiler ve iletişim modelleri üzerine yaptıkları çalışmaları en yüksek atıf patlamasına sahip çalışma olarak bulunmuştur. Ayrıca en çok araştırılan araştırma konuları sırasıyla küresel değişim, blog aracılı kriz iletişim modeli ve paydaş ilişkileri olarak tespit edilmiştir.

Anahtar Kelimeler: Halkla ilişkiler, halkla ilişkiler modelleri, Grunig, bibliyometrik analiz, CiteSpace ॥

\section{INTRODUCTION}

As a critical component of an organization's strategic management process (Grunig, \& Grunig, 2000) public relations benefits from communication in order to build and maintain relations with the most strategic publics that affect and restrain the mission of the organization (Grunig, 1992). In this line, Cutlip, Center, and Broom (1994) suggest that public relations is regarded as "the management function that establishes and maintains mutually beneficial relationships between an organization and the publics on whom its success or failure depends" (p. 2) by balancing the interests of both strategic publics and organizations (Ledingham, 2003, p. 181). At this point public relations has been conceptualised as a strategic management function rather than as media relations and publicity (Grunig, 2006). Because there is a significant transformation in the function of public relations; the publics have immense impact on the organisations in the context of the purpose and direction of the organisation (Ehling, 1992). Within that perspective, one-way communication or asymmetrical directions of the relationship cannot be efficient in order to balance the interest of both sides. Thus it can be said that the relationship between publics and the organisation can be defined by researching public relations models applied in the organisation. This is because, as Holtzhausen, Petersen \& Tindall (2003, p. 308) indicate, the models induce daily life public relations facilities of public relations practitioners' behaviour.

Though the term of model cannot apprehend the reality as a whole Grunig and Grunig (2002) refer to the term "model" as representation of reality. The models can characterize a set of values and a pattern of behaviour that refer to the way of public relations facilities. Public relations models can be considered as a reflection of the practice and understanding of public relations showing the historical sense of change 
and development (Ertürk, \& Berkman, 2016). Since Grunig and Hunt (1984) defined four models of public relations, a great deal of scholars from different countries have researched the models (Alanazi, 1996; Chen, \& Culbertson, 1992; Cooper-Chen, \& Kaneshige, 1996; Ekachai, \& Komolsevin, 1996; Erendağ Sümer, 2013; Grammer, 2005; Grunig, L. A, Grunig, Sriramesh, Huang, \& Lyra, 1995; Kim, \& Hon, 1998; Ni, 2006; Pratt, \& Ugboajah 1985; Raman, \& Karan, 2006; Sharpe, \& Simoes, 1996; Sriramesh, Kim, \& Takasaki, 1999; Sriramesh, 1992; Sriramesh, \& Vercic 2001) in order to reveal the current statues of public relations. While these studies introduce the models in a cultural context, this paper deals with the topic of public relations models as a holistic approach using bibliometric analysis. Thus the importance of this study is to show the general variation in the field of public relations by demonstrating the trends in the field. While public relations literature presents models by pointing out the development of the field in a specific country or countries, this study focuses on examining the models using bibliometric analysis thus envisaging the trends of the field.

Bibliometric analysis enables researchers to show publishing patterns as it finds out the stream of knowledge and the development of literature in a specific discipline. In the field of public relations, bibliometric analysis of public relations journals (Ki, Pasadeos, \& Ertem-Eray, 2019; Pujol, Matilla, \& Hernandez, 2018) female authors (Balta Peltekoğlu, \& Tozlu, 2018), Habermasian theory in public relations (Buhmann, Ihlen, \& Stockdale, 2019) influential authors and works in the field (Pasadeos, Renfro, \& Hanily, 1999) dialogue (Morehouse, \& Saffer, 2018) and public relations in Spanish media (Miguez-Gonzalez, Baamonde-Silva, \& Corbacho-Valencia, 2014) have been researched bibliometrically. In this context, as public relations models refer to the reflection of the practice, the central focus of this paper is to analyse the models bibliometrically. Thus the aim of the study is to reveal the trends in the field of public relations by examining the topic of "public relations models" in order to capture the variation in public relations practice.

Four models of public relations described by Grunig and Hunt (1984) are used as a means of comprehending the position and the practice of public relations. The models, which represent the historical process of the field, refer to the existing position of public relations practices (Kim, \& Hon, 1998; Laskin, 2009; Liu, \& Horsley, 2007) and they enable researchers to explain what public relations is and what it contributes to the functions of an organization (Grunig, 1983). According to Laskin (2009, p. 37) the models can be regarded as the most predominant theoretical paradigm in the field of public relations. 
The models stem from two dichotomous dimensions: the balance of intended effect and direction. While direction refers to one-way and two-way communication, balance of intended effect refers to asymmetry and symmetry. Press agentry and publicity models are conceptualised as one-way communication while, two-way asymmetrical, two-way symmetrical and mixed-motive models' direction is two-way communication. Grunig and Grunig (1989) declared that the balance of intended effect of the mixed-motive model and two-way symmetrical model is symmetrical; the other three models are asymmetrical. They also characterised four models which are respectively press agentry model, publicity model, two-way asymmetrical model, and two-way symmetrical model, as craft and professional public relations. Professional public relations refers to strategic public relations. While the press agentry model and public information model are considered as craft public relations, strategic public relations requires a mixed-motive model, two-way asymmetrical model, and two-way symmetrical model. Accordingly, the role of craft public relations relies on publicity and information dissemination. Strategic public relations focuses on managing public relations strategically by conducting research for developing dialogue with critic publics (Kim \& Hon, 1998, p. 158). Also, strategic public relations, as Grunig et al., (1995) suggest, can be determined in the two-way models, which are aligned from persuasion to dialogue.

The press agentry/publicity model, which is based on propaganda, does not take into consideration the concept of telling the truth (Grunig, \& Hunt, 1984), thus it is considered as the least effective and most doubtful in terms of ethics, (Gordon \& Kelly, 1998). This model is founded on positive publicity thus it hides negative information about the organisation from the public (Sriramesh, Kim, \& Takasaki, 1999, p. 277).

On the other hand, the second model, the public information model focuses on disseminating truthful information. This model was developed as a reaction to attacks on organisations by muckraking journalists. Organisations recognised the need for their own journalists as public relations practitioners more than the propaganda of press agents to write press handouts explaining their actions. The practitioners in this model write positive, truthful and accurate information about the organisations (Grunig, \& Grunig, 2002). Thus the practitioners are regarded as neutral disseminator of information by performing as a journalist (Grunig et al., 1995).

The two-way asymmetrical model, as the third model, is conceptualised as "engineering of consent", where the direction of communication is two-way, albeit 
unbalanced. This model leaves the organisation as it is, but manipulates the public to behave as the organisation demands. The organisation tries to influence the publics to reinforce it and behave as it wants them to behave by using research methods in order to get feedback from publics. Thus this model is also defined as scientific persuasion (Grunig, \& Grunig, 2002).

Unlike the two-way asymmetrical model, the fourth model or two-way symmetrical model, which is regarded as the ideal model by Grunig and Grunig (2002), is a balanced model. Mutual understanding between the publics and the organisation is the main objective of this model. The two-way symmetrical model concentrates on relationshipbuilding (L. A. Grunig, Grunig, \& Dozier, 2002) in order to adapt organisations' strategies to maintain strategic publics'needs (Dozier, Grunig, \& J. E. Grunig, 1995; Murphy, 1991). In this model the goal of the communication is to manage conflict and improve understanding with strategic publics using research methods. However, the aim of the research in this model is not to determine the messages in order to manipulate or persuade the publics, but to understand and communicate with them. The symmetrical model aims to develop the relationship between the strategic publics and the organisation (Grunig, 1992).

Although the symmetrical model is viewed as an ideal and excellent model, it is considered as a normative model, because there are some criteria in order to be applied in practice. It is an excellent model when the structure of the organisation is organic, when the environment is turbulent and chaotic, when the culture of the organisation is participative, when the organisation respects dialogue with the publics, and when the practitioners have knowledge of the symmetrical model (Grunig, 2006). Despite dominating the theoretical paradigm in the field of public relations (Gower, 2006), a great number of scholars (Berger, 1999; Cancel, Cameron, Sallot, \& Mitrook, 1997; Curtin, \& Gaither, 2005; Holtzhausen, \& Voto, 2002; Leichty, \& Springston, 1993; Pieczka, 1996) have criticised the model. Thus Grunig, Grunig, and Dozier (2002) have proposed a fifth model called the mixed-motive model based on these criticisms, depending on Murphy's (1991) game theory research and Excellence Study (Dozier et al., 1995).

The mixed-motive model combines both asymmetrical and symmetrical perspectives in order to gain the long-term objectives of the two-way symmetrical model (Grunig, \& Grunig, 1996) by enabling the usage of communication styles to suit the internal and external environments (Tindall, 2007). According to Plowman (1998, p. 244), asymmetrical tactics can be used in order to achieve symmetrical ends in mixed-motive model. Both 
the organisation and its publics pursue their own interests in the relationship and the outcome of this relationship should be acceptable to both sides in this model. In this process it is necessary fora middle position between both interests on the equilibrium to be found (Grunig, \& Grunig, 1996). Rather than placing the two-way asymmetrical model at one end of a continuum and the two-way symmetrical model at the other end, the mixed-motive model is placed in the middle of the continuum, which involves a symmetrical win-win zone for both the organisation and the publics (Grunig, 2001, p. 25). Named also as the new contingency model (Grunig, 2001), this mixed-motive model focuses on balancing advocacy and accommodation (Grunig et al., 2002). Negotiations and collaboration are strategies in this model to find common ground for the organisation and its publics in this win-win zone (Dozier et al., 1995). Thus this model presents a model of how excellent public relations departments balance the interest of their organisations and the publics (Grunig, 2001, p. 27).

\section{AIM AND METHODOLOGY}

The aim of the study is to reveal the trends in the field of public relations by examining the topic of "public relations models" in order to capture the variation in public relations practice. Bibliometric analysis was chosen as methodology in this study in order to show publishing patterns as bibliometric analysis finds out the stream of knowledge and the development of literature in a specific discipline (van Raan, 2005, p. 134). Bibliometric analysis is defined as a quantitative method that provides assessment of publication patterns by statistical and mathematical calculation (Özköse, \& Gencer, p.357). In that sense it comprises general descriptive statistics such as journals, papers, books and influential authors. Most of the research on bibliometric analysis depends on big data analysis and most of the data obtained from publications in Web of Science (WoS) or Scopus are analysed (Yalçıntaş, 2018, p.161). One of the most advantageous aspects of bibliometric analysis is its objectivity because citation data serve as a documentary and quantitative indicator for assessing research performance (White Paper Bibliometrics, 2020).

Bibliometric analysis is conceptualised as the statistical analysis of academic documents and is an effective method for investigating how a field of research arises over time (Zhang, Chen, Wang, \& Pablos, 2016, p. 1131). Specific research themes can be investigated through bibliometric analysis (Güzeller, \& Çeliker, 2019, p. 108) which is a set of statistical methods assessing the publication performances of countries, 
institutions, authors, and themes within the obtained data from written sources such as books, articles, proceedings and journals (Köseoğlu, 2016). Furthermore, it enables a map of publishing activities in a field to be reported and it facilitates the comprehension of differences in the impact of academics, institutions and publications (Pasadeos, Berger, \& Renfro, 2010), by mapping their structures and dynamics on databases (Köseoğlu, 2016). Also, bibliometric analysis presents influential summary information on significant scholars, research and research trends (Güzeller, \& Çeliker, 2019, p. 108) which is considered as practical for researching longitudinal trends in academic world by comprehensive coverage of a topic (Borgman, \& Rice, 1992).

Accordingly, data used in this research have been collected from Web of Science Database. In this regard, we searched the topic of 'public relations model' in the search button. 8216 studies were found in 100 different fields such as economics, hospitality leisure sport tourism, remote sensing, clinical neurology, and geography on $17^{\text {th }}$ December 2019. Among these fields we filtered the field of communication and thus 595 studies were bibliometrically analysed in the field of communication between 1982 and 2019 with the topic of "public relations models."

595 studies were investigated within the context of institution and country collaboration, co-citation network analysis, co-word network analysis and citation burst. In order to perform these network analyses, CiteSpace II software package, a Java application which supports visual exploration with knowledge domain in bibliometric database (Synnestvedt, Chen, \& Holmes, 2005, p. 725), was used. Designed by Chen, CiteSpace is a visual document analysis software which shows the development trend of a specific field in a particular period of time, and explores the pioneers of the studies (Yu, Zu, \& Fujita, 2019, p. 460). CiteSpace Il is a tool for visualizing emerging trends and citation patterns in scientific literature (Chen, 2006). It was developed to simplify the analysis of scientific literature by enabling academics to find prominent patterns from a diverse range of attributes (Chen, Song, Yuan, \& Zhang, 2008, p. 235). CiteSpace II is considered as an effective social network analysis which can be used as a method for analysing the model and the nature of relationships within the members of a specific field (Hu, \& Racherla, 2008, p. 303). On social networks, each actor's position is considered as a node that can be tied to a line symbolising the relationship between actors. According to Chen, Fu and Chang (2017), the figure formed by the node and line is conceptualised as a social network structure. In this study we aimed to research the social network structure of the public relations model. Thus the density of the network, 
modularity value, and mean silhouette value were calculated in the study. The network density refers to both the frequency and the density of relationships between each node within the graphic (Chen et al., 2017). It is considered as the ratio of observed edges to possible edges in a network (Youngblood, \& Lahti, 2018), thus referring to the distinctiveness of a sub group within the entire network (Vogel, \& Güttel, 2013). Modularity value, which is represented from 0 to 1 (the values close to 1 show a close relationship), measures the strength of division of a network into modules. Networks with high modularity are considered to have dense connections between the nodes within modules (Liu, \& Mei, 2016). A mean silhouette value, which is represented from -1 to 1 , measures the homogeneity or consistency of the cluster (Li, Reniers, Cozzani, \& Khan, 2017) and thus the values close to 1 indicate the actors in the network that are consistent and similar (Li, Ma, \& Qu, 2017).

Furthermore, centrality measures were calculated in order to evaluate the collaboration of institution and country, co-word network analysis, co-citation network analysis, and citation burst. The centrality degree describes the significance of the position of the node in the network and focuses significant points (Zhang et. al., 2016). The position of terms used in the study were evaluated in line with betweenness centrality. The betweenness centrality was conceptualized for each node in a network to measure the extent to which a node is connected to other nodes which are not connected to each other ( $\mathrm{Ni}$, Sugimoto, \& Robbin, 2017). The countries, authors and keywords were also investigated according to their rate of citation burst. As a metric presenting a sharp increase in the number of specific references in a particular time, the citation burst can provide research trends examined in the citation period (Güzeller, \& Çeliker, 2019). The study also researched co-citation networks in the field of public relations models. This analysis refers to finding out key current research topics, observing research trends, and the development of a foundation for the future. Thus it enables researchers to use a methodology for representing the relationship between the core ideas of a specific field (Ferreira, Fernandes, \& Ratten, 2016).

\section{FINDINGS}

\section{Collaboration of Institution and Country}

The nodes in the network refer to institutions and countries whereas the connections express the relationships among them. While Figure 1 shows the institutions' 
collaborations, Figure 2 shows country collaborations. While high centrality is shown by the thickness in Figure 1, the circles around the nodes as indicated in Figure 2 refer to high centrality. The network of institution of collaboration on the topic of public relations models as shown in Figure 1 is composed of 53 nodes and 23 connections. The density of the network was found to be 0.015 . Modularity value was found as Q:0.79 and mean silhouette value was 0.24 . The modularity value implies a well-structured network (Chen, Ibekwe-SanJuan, \& Hou, 2010).

While each node represents an institution, each connection represents a relationship among institutions. According to Figure 1, the University of Tennessee is the top ranked institution by centrality on the topic of the public relations models. When collaborations among universities were investigated, the University of Tennessee can be defined as a form of link that attaches to other institutions such as the University of Houston, the University of Syracuse, the University of Alabama and the University of Fribourg. On the other hand, the University of Maryland has collaboration with just Virginia Commonwealth University on the topic of public relations models.

The top ranked item by citation counts of institutions was Syracuse University in the USA. Table 1 indicates the frequency values of the top 10 universities. As eight universities of the 10 top universities are in the USA, it can be said that institutions from the USA dominate the field of public relations. The top ranked universities are respectively; the University of Houston, the University of Maryland, the University of Tennessee, the University of Alabama, the University of Florida, the University of Amsterdam, Indiana University, the University of Colorado, and the University of Fribourg.

The network of country collaboration on the topic of public relations models shown in Figure 2 is composed of 26 nodes and 33 connections. The density of the network was found to be 0.10 . The modularity value was Q:0.41 suggesting that the structure was reasonable (Newman, 2004) and the mean silhouette value was 0.43 representing that the actors in the network were consistent (Li et al., 2017). While each node represents a country, each connection represents relationship among countries. According to Figure 2, the USA was the top ranked country by centrality on the topic of public relations models. The central countries researching public relations models were respectively the USA, England, Australia, Singapore, Switzerland and Germany. The Netherlands were found to be outside of the collaborations as the University of Amsterdam in Figure 1. 
The top ranked item by citation counts of countries was found to be the USA. Table 2 indicates the frequency values of the top 10 countries. The top ranked countries by citation counts were respectively the USA, England, Spain, Australia, South Korea, South Africa, Switzerland, the Netherlands, Germany, and Singapore. Using node centrality as a metric, the USA and England have significant positions in this field. The centrality value for the USA was 0.98, and the centrality value for England was 0.28 (Table 2).

Moreover, countries were investigated in terms of their rate of citation burst and the highest burst frequency was found to be South Korea as given in Table 3. The finding of Table 3 indicates that authors from South Korea between 2007 and 2012 had a high citation frequency.

\section{Keyword Network Analysis}

Keyword network analysis is a method to clarify the structure of scientific knowledge and the research topics (Su, Li, \& Kang, 2019). High-frequency keywords and central keywords can be considered as part of the knowledge base of the field (Shi \& Liu, 2019). We investigated research hotspots in the field of public relations models by keyword network analysis. Keywords in the 595 studies were researched and the findings were given in Figure 3. There were 182 nodes and 1,009 connections identified in the network of public relations models. The network was divided into seven clusters and the density was 0.06 . Modularity $Q$ was found to be $0.35>0.3$, and the structure was considered as reasonable (Newman, 2004). Silhouette score was found to be $0.71>0.4$, and the result was evaluated as quite reasonable (Rousseeuw, \& Kaufman, 1990). The top ranked keywords by centrality on the topic of public relations models were respectively communication, crisis communication, impact, public relations, dialogue, organisation, management, and perception.

Both the top ranked item by citation counts of keywords and the top ranked centrality values of keywords were shown in Table 4 . While the top keywords by frequency were found respectively to be public relations, model and social media, the top keywords by centrality were found respectively to be communication, crisis communication and impact. Also, the network of keyword was divided into seven co-citation clusters. These clusters were labelled by index terms from their own citers. The largest two clusters were indicated in Table 5. According to Table 5, the largest cluster had 38 members and a silhouette value of 0.722 , while the second largest cluster had 29 members and 
a silhouette value of 0.769 . The first cluster was labelled as comparative analysis by the log-likelihood ratio (LLR), and was labelled as public relations by term frequency-inverse document frequency (TFIDF). The second cluster was labelled as crisis information by LLR, treatment by TFIDF.

Moreover, the keywords were investigated in terms of their rate of citation burst. The highest burst frequencies were found to be "public relations" and "models" as given in Table 6. Burstiness measures generally show the searched topic of the research as expected. Thus this finding should be evaluated in terms of a period (years) in order to provide the trend timeline. The findings of Table 6 indicate that authors who researched "public relations" between 2003 and 2010 and authors who researched "model" between 2007 and 2014 had high citation frequency.

\section{Co-citation Network Analysis}

595 studies cited 23,383 studies in the topic of public relations models as shown in Figure 4. There were 475 nodes and 1680 connections in the co-citation network. The network was divided into 13 co-citation clusters and the density was 0.01 . Modularity value was found to be Q:0.80 suggesting a well-structured network (Chen et al., 2010) and the mean silhouette value was 0.40 which is an indicator of a good clustering (Jiang, Ritchie, \& Benckendorff, 2017, p. 80). The most studied topics of public relations models were found to be global flux, blog-mediated crisis communication model, stakeholder relationship, deliberative system, public relations agencies, and single case study.

The study also examined the top ranked studies by centrality and frequencies in order to find out influential studies and authors in the field. Whereas Table 7 shows the top ranked documents by centrality, Table 8 shows the top ranked documents by frequency. According to Table 7, the top ranked cited studies by centrality on the topic of public relations models were, respectively, studies by Kim (2011), Johnston (2014), Cho et al. (2014), Banks (2011), Heath (2006), Taylor, \& Kent (2014), Eyrich et al., (2008), Kim, \& Grunig (2011), Taylor (2011), and Mishra et al. (2014).

Frequency values of top cited documents were researched in Table 8. According to Table 8, the top ranked cited studies by frequency on the topic of public relations models were, respectively, studies by Taylor, \& Kent (2014), Curtin, \& Gaither (2007), 
L'Etang, \& Pieczka (2011), Eyrich et al., (2008), Kim, \& Grunig (2011), Kim (2011), Kent (2013), Sriramesh, \& Vercic (2009), Ki, \& Hon (2007), and Waters et al. (2009).

Furthermore, the authors were investigated according to their rate of citation burst. The top ranked items by bursts was Grunig and Grunig (2002) in Cluster \#7, with bursts of 4.79. The second one was Ki and Hon (2007) in Cluster \#4, with bursts of 3.96 as given in Table 9. The finding of Table 9 indicates that the chapter explaining the models in the book titled Excellent Public Relations and Effective Organisations by Grunig and Grunig from 2007 and 2010 had a high citation frequency and the article titled "Testing the Linkages Among the Organization-Public Relationship and Attitude and Behavioral Intentions" by Ki and Hon from 2009 and 2014 had a high citation frequency.

Moreover, it is important to research the trend topics in the co-citation network. It was found that the network is divided into 13 co-citation clusters. These clusters indicate the trend topic in the field of public relations models. To check the quality of the clustering results, the silhouette score was investigated, and its value for each cluster was found to be higher than 0.8 thus indicating a high-quality clustering result (Rousseeuw, \& Kaufman, 1990). Furthermore, the number of publications in each cluster was moderately high. The highest was 54 studies, and the lowest was 35 studies. Therefore, it can be said that academics have reached a consistent research theme in this field. These clusters were labelled by index terms from their own citers. The largest 5 clusters were summarized in Table 10. In the context of topic clusterings of the studies published in the topic of public relations models, 13 clusters were obtained in total, and the 5 clusters with the highest dimension were given in Table 10. The topics and the related clusters show the topic trends and existing tendency in the field of public relations. According to the results, the most investigated research topics were global flux ( $n=54)$, blog-mediated crisis communication model $(n=40)$, stakeholder relationship ( $n=37)$, deliberative systems $(n=35)$, and public relations agencies $(n=35)$. Thus it can be inferred that this bibliometric study presents a significant contribution to scholars researching in the field of public relations by outlining the research trends and by identifying the most dominant research topics.

\section{DISCUSSION AND CONCLUSION}

Previous studies researching the field of public relations bibliometrically through public relations journals have suggested for future studies to be carried out using 
similar bibliometric analyses in a specific subfield of public relations (Ki et al., 2019; Morehouse, \& Saffer, 2018; Pasadeos et al., 1999). As public relations is an interdisciplinary field, and public relations academics tend to publish their studies in journals of other disciplines, it is more convenient to research "the topic" bibliometrically rather than to research the journals. The study, aiming to find out the trends in the field of public relations by examining the topic of "public relations models", has captured the variation in public relations practice. According to the findings of the study, firstly the USA as a country, universities in the USA as institutions, and academics from the USA as author collaboration showed that the USA with its institutions and author collaboration was the top ranked country on the topic of public relations models. This finding is congruent with the fact that public relations models developed in the United States in particular (Holtzhausen et al., 2003). Also, England was found to be the second dominating country, as Grunig et al. (1995) indicate that public relations is a major force in organizational communication in the USA and other Western countries. However, the Netherlands and the University of Amsterdam were found to be outside of the collaborations. It can be inferred that there is a difference between the USA and Northern European countries in terms of the public relations paradigm. While the USA approaches public relations from organisational effectiveness (the impact on public relations on organisational effectiveness), Northern European countries approach public relations from a societal perspective (the impact of public relations on societal improvement).

As James Grunig is regarded as the founding father of modern public relations thinking and the author of the models (Moloney, 2004), he and Larissa Grunig are considered to be the top ranked authors in this study. Much research in the field of public relations has used models based on their studies. Also, a great number of studies have focused on Symmetry/Excellence Theory in the field (Botan, \& Hazleton, 2006). This finding is also congruent with the bibliometric analysis by Ki et al. (2019) suggesting that James Grunig is the most cited public relations author between the periods of 1990-1995, 2000-2005 and 2010-2015.

When citation burst of countries, authors and topic were evaluated, the years from 2007 to 2014 were found to have the highest citation frequency. It can be inferred that the topic of public relations models was the trending topic between those years. It can be said that research topics in public relations shifted to new topics after 2014, as Ki et al. (2019) stated that the most frequently researched topics shifted from 1990 to 2015 in public relations journals. In their study, models were listed among the most 
frequently researched topics between 1990-1995 in public relations journals. It can be inferred that, while the models were one of the mostly researched topics in the field of public relations between 1990 and 1995 in the journals, this current study found out that models were a trending topic between 2007 and 2014 within the context of models. In order to find out current trend topics, it is suggested that new studies bibliometrically research pioneering journals in the field of public relations, especially those published after 2015.

When the top ranked keyword by centrality on the topic of public relations models was investigated, it was found that crisis communication, public relations, dialogue, communication, impact, organisation, management, reputation, strategy and model were dominating the field. Previous bibliometrical studies examining journals carried out in the field of public relations in order to find out the trend topics, identified similar concepts to our study, such as crisis communications, management, and relationship (Ki, et al., 2019). This finding provides an important insight for the field in terms of capturing the variation in public relations practice by examining the topic of "public relations models". This finding supports the view that researching the models is a means of comprehending the position and the practice of public relations and thus explaining what public relations is.

These concepts are also in parallel with the most investigated research topics, which are global flux, blog-mediated crisis communication model, stakeholder relationship, deliberative systems, and public relations agencies. The fact that global flux is the main trend topic can be related to the shift in the public relations paradigm. In today's continually changing organizational environment, organizations have to change their strategic direction to sustainability (Bordia et al., 2004) and at this point public relations becomes a key driver for organizations in order to achieve their goals and legitimacy. Organisational legitimacy can be ensured by societal and stakeholder expectations, values, norms and standards for good corporate governance and socially responsible behaviour, rather than only by government regulations (Steyn, \& Niemann, 2010). Thus stakeholder relationships have become more important than ever as legitimacy occurs only when the organisation's actions are parallel with the expectations' of society (Sutton, 1993). So it can be suggested that organisations are dependent on society for legitimisation to gain a favourable reputation and to be conceived as societally responsible (Steyn, \& Niemann, 2010; Steyn, 2009). 
When the trend topics such as global flux and stakeholder relationship were evaluated, it suggested that symmetrical model and mixed-motive model can dominate the field of public relations in the near future. Firstly, because of a turbulent environment, which is a requirement of the symmetrical model, we can envisage that global flux is a reflection of this environment. In order to manage the conflict in this environment, public relations practitioners should focus on symmetrical model or mixed-motive model by enabling the styles of communication to adapt to the internal and external environments. Secondly, stakeholder relationships are also related to both symmetrical model and mixed-motive model as the importance of dialogue with the publics is a requirement of the symmetrical model. Thus we can explain the two-trend topic, namely, global flux and stakeholder relationships with the need for both symmetrical model and mixed-motive model whose outcomes are acceptable to both the organisation and publics.

Furthermore, it can be suggested that relationships should be built online with the stakeholders as blog-mediated crisis communication has been found to be one of the main trend topics. While previous bibliometric studies in the field of public relations have demonstrated crisis communication as a trend topic (Ki, et al., 2019), our research indicates the need for online/digital crisis communication. It can be recommended that while academics need to include online dialogue strategies and digital dialogic communication into their curriculum, practitioners need to be ready for social-mediated crisis communication strategies for an effective issue monitoring process.

In summary, having been practised as media relations and publicity in an asymmetrical manner in the past, public relations has now transformed into strategic communication management in a symmetrical manner in order to build relations with the key stakeholders and publics. The findings of this study have solidified this transformation in the field by identifying the trend topics as global flux, stakeholder relationships and blog-mediated crisis management. All of these trends indicate the need for a symmetrical perspective. Furthermore, in that symmetrical context we foresee that digital dialogic communication can be the prioritising concept of the public relations discipline in the future.

Peer-review: Externally peer-reviewed.

Conflict of Interest: The authors has no conflict of interest to declare.

Grant Support: The authors declared that this study has received no financial support. 


\section{REFERENCES}

Alanazi, A. (1996). Public relations in the Middle East: The case of Saudi Arabia. In H. M. Culbertson, \& N. Chen (Eds.), International public relations. A comparative analysis (pp. 239-256). Mahwah, NJ: Lawrence Erlbaum Associates, Inc.

Balta-Peltekoğlu, F., \& Tozlu, E. (2018). The bibliometric profile of articles written by female authors in the field of public relations at refereed journals of communicatıon faculties in Turkey. Marmara Üniversitesi Kadın ve Toplumsal Cinsiyet Araştırmaları Dergisi, 2(2), 55-65. https://doi.org/10.26695/mukatcad.2018.17

Berger, B. K. (1999). The Halcion affair: Public relations and the construction of ideological world view. Journal of Public Relations Research, 11, 188-189. https://doi.org/10.1207/s1532754xjprr1103_01

Bordia, P., Hobman, E., Jones, E., Gallois, C., \& Callan, V. J. (2004). Uncertainty during organizational change: types, consequences, and management strategies. Journal of Business and Psychology, 18(4), 507-532. https://doi. org/10.1023/B:JOBU.0000028449.99127.f7

Borgman, C. L., \& Rice, R. E. (1992). The convergence of information science and communication: a bibliometric analysis. Journal of The American Society for Information Science, 43(6), 397-411. https://doi.org/10.1002/ (SICI)1097-4571(199207)43:6<397::AID-ASI1>3.0.CO;2-M

Botan, C. H., \& Hazelton, V. (2006). Public relations in a new age. In C. H. Botan, \& V. Hazelton (Eds.), Public relations theory II (pp. 1-18). Mahwah, NJ: Lawrence Erlbaum Associates.

Buhmann, A., Ihlen, Ø., \& Aaen-Stockdale, C. (2019). Connecting the dots: A bibliometric review of Habermasian theory in public relations research. Journal of Communication Management, 23(4), 444-467. https://doi. org/10.1108/JCOM-12-2018-0127

Cancel A. E., Cameron G. T., Sallot L. M., \& Mitrook M. A (1997). It depends: A contingency theory of accommodation in public relations. Journal of Public Relations Research, 9(1), 31-63. https://doi.org/10.1207/ s1532754xjprr0901_02

Chen, C., Song, Y., Yuan, X. \& Zhang, J. (2008). The thematic and citation landscape of data and knowledge engineering (1985-2007). Data \& Knowledge Engineering, 67, 234-259.

Chen, C. (2006). CiteSpace II: detecting and visualizing emerging trends and transient patterns in scientific literature. Journal of The American Society For Information Science and Technology, 57(3):359-377. DOI: 10.1002/asi.20317

Chen, C., Fu, X., \& Chang, C. Y. (2017). A terms mining and clustering technique for surveying network and content analysis of academic groups exploration. Cluster Computing, 20(1), 43-52. https://doi.org/10.1007/ s10586-016-0711-5.

Chen, C., Ibekwe-SanJuan, F., \& Hou, J. (2010). The structure and dynamics of cocitation clusters: a multipleperspective cocitation analysis. Journal of The American Society for Information Science and Technology, 61(7), 1386-1409. 
Chen, N., \& Culbertson, H. M. (1992). Two contrasting approaches of government public relations in Mainland China. Public Relations Quarterly, 37(3), 36-41. Retrieved from https://search.proquest.com/openview/5438b cbfdc6bd08cd96d0e56aa9da6ce/1?cbl=49209\&pq-origsite=gscholar

Pujol M., Matilla K., \& Hernandez S. (2018). Strategy and public relations: Bibliometric comparative study. Revista Latina de Comunicacion Social, 73, 748-764. https://doi.org/10.0.16.89/RLCS-2018-1280en

Cooper-Chen, A., \& Kaneshige, M. (1996). Public relations practice in Japan: Beginning again for the first time. In H. M. Culbertson, \& N. Chen (Eds.), International Public Relations. A Comparative Analysis (pp. 223-237). Mahwah, NJ: Lawrence Erlbaum Associates, Inc.

Curtin, P. A., \& Gaither, T. K. (2005). Privileging identity, difference, and power: The circuit of culture as a basis for public relations theory. Journal of Public Relations Research, 17(2), 91-115. https://doi.org/10.1207/ s1532754xjprr1702_3

Cutlip, S., Center, A., \& Broom, G. (1994). Effective Public Relations. New Jersey, NJ: Prentice Hall International Edit. Dozier, D. M., Grunig, L. A., \& Grunig, J. E. (1995). Manager's Guide to Excellence in Public Relations and Communication Management. Mahwah, NJ, Lawrence Erlbaum Associates, Inc.

Ehling, W. P. (1992). Estimating the value of public relations and communication to an organisation. In J. E. Grunig (Ed.), Excellence in Public Relations and Communication Management (pp. 617-638). Hillsdale, NJ: Laurence Erlbaum Associates.

Ekachai, D., \& Komolsevin, R. (1996). Public relations in Thailand: Its functions and practitioners' roles. In H. M. Culbertson, \& N. Chen (Eds.), International Public Relations. A Comparative Analysis (pp. 155-170). Mahwah, NJ: Lawrence Erlbaum Associates, Inc.

Erendağ-Sümer, F. (2013). Türkiye'de stratejik halkla ilişkiler anlayışı: Türkiye'deki büyük iş örgütlerinin halkla ilişkiler uygulayıcılarına yönelik bir araştırma. Global Media Journal: Turkish Edition. 4(7), 51-80. Retrieved from https://globalmediajournaltr.yeditepe.edu.tr/sites/default/files/Fulya\%20ERENDAG\%CC\%86\%20 SU\%CC\%88MER.pdf

Ertürk, K., \& Berkman, A. (2016). Corporate governance as a communication policy in two-way symmetrical public relations model. Niğde Üniversitesi İktisadi ve Idari Bilimler Fakültesi Dergisi, 9(2), 61-73. Retrieved from https://dergipark.org.tr/en/pub/niguiibfd/issue/19762/211677

Ferreira, J. M., Fernandes, C. I., \& Ratten, V. (2016). A co-citation bibliometric analysis of strategic management research. Scientometrics, 109, 1-32.

Grammer, M. E. (2005). An exploration of the generic principles of public relations excellence in Australia, Italy, Mauritius and Uganda (MA Thesis, University of Maryland, College Park). Retrieved from https://drum.lib. umd.edu/handle/1903/2926

Grunig, J. E. (1992). Communication, public relations, and effective organizations: An overview of the book. In J.

E. Grunig (Ed.), Excellence in Public Relations and Communication Management (pp. 1-28). Hillsdale, NJ: Lawrence Erlbaum Associates, Inc. 
Grunig, J. E. (2006). Furnishing the edifice: ongoing research on public relations as a strategic management function. Journal of Public Relations Research, 18(2), 51-176. https://doi.org/10.1207/s1532754xjprr1802_5

Grunig, J. E., \& Grunig, L. A. (1989). Toward a theory of the public relations behaviour of organizations. Public Relations Research Annual, 1, 27-66. https://doi.org/10.1207/s1532754xjprr0101-4_2

Grunig, J. E., \& Grunig, L. A. (1996). Implications of symmetry for a theory of ethics and social responsibility in public relations. Paper presented to the Annual Conference of the International Communication Association, Chicago.

Grunig, J. E. (2001). Two-Way Symmetrical Public Relations, Past, Present, Future. In R. L. Heath (Ed.), Handbook of Public Relations (pp. 11-50). London: Sage Publications.

Grunig, J. E., \& Grunig, L. A. (2002). Models of public relations and communication. In J. E. Grunig (Ed.), Excellence in Public Relations and Communication Management (pp. 285-325). Hillsdale, NJ: Lawrence Erlbaum Associates, Inc.

Grunig, J. E., \& Grunig, L. A. (2000). Research methods for environmental scanning. J. and L. Grunig's Research: $A$ Supplement of PR Reporter, 7, 1-4.

Grunig, J. E., \& Hunt, T. (1984). Managing Public Relations. Fort Worth, TX: Holt, Rinehart \& Winston.

Grunig, J. E., Grunig, L. A., Sriramesh, K., Huang, Y.-H., \& Lyra, A. (1995). Models of public relations in an international setting. Journal of Public Relations Research, 7, 163-186. https://doi.org/10.1207/ s1532754xjprr0703_01

Grunig, J. E. (1983). Communication behaviors and attitudes of environmental publics: Two studies. Journalism Monographs, 81. Retrieved from https://www.researchgate.net/publication/239466448_Communication_ Behaviors_and_Attitudes_of_Environmental_Publics_Two_Studies

Grunig, J. E., Grunig, L. A., \& Dozier, D. M. (2002). Excellent Public Relations and Effective Organisations: A Study of Communication Management in Three Countries. Mahwah, NJ: Lawrence Erlbaum Associates.

Güzeller, C. O., \& Çeliker, N. (2019). Bibliometrical analysis of Asia Pacific Journal of Tourism Research. Asia Pacific Journal of Tourism Research, 24(1), 108-120. https://doi.org/10.1080/10941665.2018.1541182

Holtzhausen D., \& Voto, R. (2002). Resistance from the margins: the postmodern public relations practitioner as organizational activist. Journal of Public Relations Research, 14(1), 57-84. https://doi.org/10.1207/ S1532754XJPRR1401_3

Holtzhausen, D. R., Petersen K., \& Tindall, N. T. J. (2003) Exploding the myth of the symmetrical/asymmetrical dichotomy: public relations models in the New South Africa. Journal of Public Relations Research, 15(4), 305341. https://doi.org/10.1207/S1532754XJPRR1504_02

Hu, C., \& Racherla, P. (2008). Visual representation of knowledge networks: A social network analysis of hospitality research domain. International Journal of Hospitality Management, 27, 302-312. https://doi.org/10.1016/j. ijhm.2007.01.002

Jiang, Y., Ritchie, B. W., \& Benckendorff, P. (2017). Bibliometric visualisation: An application in tourism crisis and disaster management research. Current Issues in Tourism, 22(16), 1925-1957. https://doi.org/10.1080/136835 00.2017 .1408574 
Ki, E., Pasadeos, Y., \& Ertem-Eray, T. (2019). Growth of public relations research networks: A bibliometric analysis. Journal of Public Relations Research, 31(1), 25-31. https://doi.org/10.1080/1062726X.2019.1577739

Kim, Y., \& Hon, L. C. (1998). Craft and professional models of public relations and their relation to job satisfaction among Korean public relations practitioners. Journal of Public Relations Research, 10, 155-175. https://doi. org/10.1207/s1532754xjprr1003_01

Köseoğlu, M. A. (2016). Growth and structure of authorship and co-authorship network in the strategic management realm: Evidence from the strategic management journal. BRQ Business Research Quarterly, 19(3), 153-170. https://doi.org/10.1016/j.brq.2016.02.001

Laskin, A. V. (2009). The evolution of models of public relations: An outsider's perspective. Journal of Communication Management, 13(1), 37-54. https://doi.org/10.1108/13632540910931382

Ledingham, J. A. (2003). Explicating relationship management as a general theory of public relations. Journal of PublicRelations Research, 15(2), 181-198. https://doi.org/10.1207/S1532754XJPRR1502_4

Leichty, G., \& Springston J. (1993). Reconsidering public relations models. Public Relations Review, 19(4), $327-339$. https://doi.org/10.1016/0363-8111(93)90055-H

Li, X., Ma, E., \& Qu, H. (2017). Knowledge mapping of hospitality research A visual analysis using CiteSpace. International Journal of Hospitality Management, 60, 77-93.

Li, J., Reniers, G., Cozzani, V., \& Khan, F. (2017). A bibliometric analysis of peer-reviewed publications on domino effects in the process industry. Journal of Loss Prevention in the Process Industries, 49, 103-110.

Liu, B. F., \& Horsley, J. S. (2007). The government communication decision wheel: Toward a public relations model for the public sector. Journal of Public Relations Research, 19(4), 377-393. https://doi.org/10.1080/10627260701402473

Liu, M., \& Mei, S. (2016). Visualizing the GVC research: A co-occurrence network based bibliometric analysis Scientometrics, 109, 953-977. https://doi.org/10.1007/s11192-016-2100-5

Miguez-Gonzalez, M. İ., Baamonde-Silva X. M., \& Corbacho-Valencia, J. M. (2014). A bibliographic study of public relations in Spanish media and communication journals, 2000-2012. Public Relations Review, 40(5), 818-828. https://doi.org/10.1016/j.pubrev.2014.08.002

Moloney, K. (2004). Debate papers: Democracy and public relations. Journal of Communication Management, 9(1), 89-92.

Morehouse, J., \& Saffer, A. J. (2018). A bibliometric analysis of dialogue and digital dialogic research: Mapping the knowledge construction and invisible colleges in public relations research. Journal of Public Relations Research, 30(3), 65-82. https://doi.org/10.1080/1062726X.2018.1498343

Murphy, P. (1991). The limits of symmetry: A game theory approach of symmetric and asymmetric public relations. In J. E. Grunig, \& L. A. Grunig (Eds.), Public Relations Research Annual 3 (pp. 115-131). Hillsdale, NI: Lawrence Erlbaum Associates, Inc.

Newman, M. E. (2004). Fast algorithm for detecting community structure in networks. Physical Review E, 69, https://doi.org/10.1103/PhysRevE.69.066133. 
Ni, L. (2006). Relationships as organizational resources: examining public relations impact through its connection with organizational strategies. Public Relations Review. 32(3), 276-281. https://doi.org/10.1016/j. pubrev.2006.05.007

Ni, C., Sugimoto, C. R. \& Robbin, A. (2017). Examining the evolution of the field of public administration through a bibliometric analysis of public administration review. Public Administration Review, 77(4), 496-509.

Özköse, H., \& Gencer, C. (2017). Bibliometric analysis and mapping of management information systems field. Gazi University Journal of Science, 30(4), 356-371.

Pasadeos, Y., Berger, B., \& Renfro, R. B. (2010). Public relations as a maturing discipline: An update on research networks. Journal of Public Relations Research, 22(2), 136-158. https://doi.org/10.1080/10627261003601390

Pasadeos, Y., Renfro, R. B., \& Hanily, M. L. (1999). Influential authors and works of the public relations scholarly literature: a network of recent research. Journal of Public Relations Research, 11(1), 29-52. https://doi. org/10.1207/s1532754xjprr1101_02

Pieczka, M. (1996). Paradigms, systems theory and public relations. In J. L'Etang, \& M. Pieczka (Eds.), Critical Perspectives in Public Relations (pp. 124-156). London, UK: International Thomson Business Press.

Plowman, K. D. (1998). Power in conflict for public relations. Journal of Public Relations Research, 10(4), $237-261$. https://doi.org/10.1207/s1532754xjprr1004_02

Pratt, C., \& Ugboajah, F. O. (1985). Social responsibility: A comparison of Nigerian public relations with Canadian and U.S. public relations. International Public Relations Association Review, 9, 22-29.

Raman, N., \& Karan, K. (2006). Cultural influences on public relations practices in multicultural societies: A study of multinational organizations in Singapore. China Media Research, 2(1), 31-42. Retrieved from https://www. chinamediaresearch.net/readmore/vol2no1/04_N_R_Kavita_K_Re-1.jpg

Rousseeuw, P. J., \& Kaufman, L. (1990). Finding groups in data. Series in Probability \& Mathematical Statistics, 34(1), 111-112.

Sharpe, M. L., \& Simoes, R. P. (1996). Public relations performance in South and Central America. In H. M. Culbertson, \& N. Chen (Eds.), International Public Relations: A Comparative Analysis (pp. 273-297). Mahwah, NJ: Lawrence Erlbaum Associates, Inc.

Shi, Y. \& Liu, X. (2019). Research on the literature of green building based on the web of science: A scientometric analysis in CiteSpace (2002-2018). Sustainability 11, 3716. https://doi.org/10.3390/su11133716

Sriramesh, K. (1992). The impact of societal culture on public relations: Ethnographic evidence from India. Public Relations Review, 18(2), 201-211. https://doi.org/10.1016/0363-8111(92)90010-V

Sriramesh, K., \& Vercic, D. (2001). International public relations: a framework for future research. Journal of Communication Management, 6(2), 103-117. https://doi.org/10.1108/13632540210806973

Sriramesh, K., Kim, Y., \& Takasaki, M. (1999). Public relations in three Asian cultures: An analysis. Journal of Public Relations Research, 11, 271-292. https://doi.org/10.1207/s1532754xjprr1104_01 
Steyn B., \& Niemann, L. (2010). Enterprise strategy: A concept that explicates corporate communication's strategic contribution at the macro-organisational level. Journal of Communication Management, 14(2), 106126. https://doi.org/10.1108/13632541011034574

Steyn, B. (2009). The strategic role of public relations is strategic reflection: A South African research stream. American Behavioural Scientist, 53(4), 516-532. https://doi.org/10.1177/0002764209347628

Su, X., Li, X., \& Kang, Y. (2019). A bibliometric analysis of research on intangible cultural heritage using CiteSpace. SAGE Open, 1-18. https://doi.org/10.1177/2158244019840119

Synnestvedt, M. B., Chen, C., \& Holmes, J. H. (2005). CiteSpace II: Visualization and knowledge discovery in bibliographic databases. AMIA Annual Symposium Proceeding, 724-728. Retrieved from https://www.ncbi. nlm.nih.gov/pmc/articles/PMC1560567/

Tindal, N. T. J. (2007). Fund-raising models at public historically Black colleges and universities. Public Relations Review, 33(2), 201-205. https://doi.org/10.1016/j.pubrev.2007.02.004

van Raan, A. F. J. (2005). Fatal attraction: Conceptual and methodological problems in the ranking of universities by bibliometric methods. Scientometrics, 62(1), 133-143. https://doi.org/10.1007/s11192-005-0008-6

Vogel, R., \& Güttel, W. (2013). The dynamic capability view in strategic management: A bibliometric review. International Journal of Management Reviews, 15, 426-446. https://doi.org/10.1111/ijmr.12000

White Paper Bibliometrics. (2020). Retrieved from http://ips.clarivate.com/m/pdfs/325133_thomson.pdf Yalçıntaş, A. (2018). Büyük veri, veri obezitesi ve kaybolan nedensellikler. Yıldız Social Science Review, 4(2), $153-166$. Youngblood, M., \& Lahti, D. (2018). A bibliometric analysis of the interdisciplinary field of cultural evolution. Palgrave Communications, 4(120). https://doi.org/10.1057/s41599-018-0175-8.

Yu, D. J., Xu, Z. S., \& Fujita, H. (2019). Bibliometric analysis on the evolution of applied intelligence. Applied Intelligence, 49(2), 449-462.

Zhang, X., Chen, H., Wang, W., \& Ordóñez de Pablos, P. (2016). What is the role of IT in innovation? A bibliometric analysis of research development in IT innovation. Behaviour \& Information Technology, 35(12), 1130-1143. https://doi.org/10.1080/0144929X.2016.1212403 


\section{TABLES AND FIGURES}

Table 1: Frequency Values of Top 10 Institutions

\begin{tabular}{|l|c|c|}
\hline Frequency & Centrality & Institution \\
\hline 10 & 0.01 & Syracuse University \\
\hline 10 & 0.03 & University of Houston \\
\hline 9 & 0.00 & University of Maryland \\
\hline 8 & 0.03 & University of Tennessee \\
\hline 7 & 0.05 & University of Alabama \\
\hline 6 & 0.00 & University of Florida \\
\hline 6 & 0.00 & University of Amsterdam \\
\hline 4 & 0.00 & Indiana University \\
\hline 4 & 0.00 & University of Colorado \\
\hline 4 & 0.00 & University of Fribourg \\
\hline
\end{tabular}

Table 2: Frequency Values of Top 10 Countries

\begin{tabular}{|l|c|c|}
\hline Frequency & Centrality & Country \\
\hline 282 & 0.98 & USA \\
\hline 43 & 0.28 & England \\
\hline 33 & 0.00 & Spain \\
\hline 24 & 0.06 & Soustralia \\
\hline 18 & 0.00 & South Africa \\
\hline 13 & 0.00 & Switzerland \\
\hline 11 & 0.01 & Netherlands \\
\hline 10 & 0.00 & Germany \\
\hline 9 & 0.01 & Singapore \\
\hline 9 & 0.04 & \\
\hline
\end{tabular}

Note: Centralities: A metric of a node measures how likely it is that an arbitrary shortest path in a network will go through the node, which shows the contribution of a node to connections with other nodes in a network (Su, Li, \& Kang, 2019).

Table 3: Countries with the Strongest Citation Bursts

\begin{tabular}{|l|c|c|c|c|c|}
\hline Countries & Year & Strength & Begin & End & $\mathbf{1 9 8 0}-\mathbf{2 0 1 9}$ \\
\hline South Korea & 1980 & 3.94 & $\mathbf{2 0 0 7}$ & 2012 & \\
\hline
\end{tabular}


Table 4: Frequency and Centrality Values of Top 20 Keywords

\begin{tabular}{|l|c|c|c|}
\hline Frequency & Keyword & Centrality & Keyword \\
\hline 197 & public relations & 0.15 & communication \\
\hline 98 & Model & 0.15 & crisis communication \\
\hline 77 & Communication & 0.15 & public relations \\
\hline 52 & social media & 0.12 & Dialogue \\
\hline 48 & Management & 0.12 & organization \\
\hline 44 & Media & 0.10 & management \\
\hline 28 & Perception & 0.08 & perception \\
\hline 21 & Organization & 0.08 & information \\
\hline 20 & Information & 0.08 & Model \\
\hline 20 & crisis communication & 0.08 & Media \\
\hline 18 & Strategy & 0.07 & Role \\
\hline 17 & Power & 0.07 & strategy \\
\hline 16 & Practitioner & 0.07 & News \\
\hline 16 & Impact & 0.06 & engagement \\
\hline 16 & News & 0.06 & reputation \\
\hline 15 & Leadership & 0.06 & social media \\
\hline 15 & Journalism & 0.06 & Practitioner \\
\hline 14 & Engagement & 0.05 & 0.05 \\
\hline 13 & corporate communication & 0.05 & \\
\hline 13 & & & \\
\hline
\end{tabular}

Table 5: Summary of the largest 2 clusters of keyword

\begin{tabular}{|c|c|c|c|c|c|c|}
\hline Cluster & Size & $\begin{array}{c}\text { Mean } \\
\text { Silhouette }\end{array}$ & $\begin{array}{l}\text { Label } \\
\text { (TFIDF) }\end{array}$ & $\begin{array}{c}\text { Label } \\
\text { (LLR) } \\
\text { p value }\end{array}$ & Lable (MI) & $\begin{array}{c}\text { Avarage } \\
\text { Citation } \\
\text { Year }\end{array}$ \\
\hline 0 & 38 & 0.722 & $\begin{array}{l}\text { public } \\
\text { relations }\end{array}$ & $\begin{array}{c}\text { comparative } \\
\text { analysis }(44.47, \\
1.0 \mathrm{E}-4)\end{array}$ & $\begin{array}{c}\text { online political public relation } \\
\text { (1.14); career experience (1.14); } \\
\text { presidential campaign (1.14); } \\
\text { public segmentation model } \\
\text { (1.14); finding publics (1.14); } \\
\text { pragmatic cultural schema } \\
\text { (1.14); stakeholder relationship } \\
\text { (1.14); British public relation } \\
\text { (1.14); analysing public relations } \\
\text { communication strategies (1.14); } \\
\text { interactivity effect (1.14); }\end{array}$ & 2013 \\
\hline 1 & 29 & 0.769 & treatment & $\begin{array}{c}\text { crisis information } \\
(46.72,1.0 \mathrm{E}-4)\end{array}$ & $\begin{array}{c}\text { online political public relation } \\
(0.4) \text {; career experience }(0.4) ; \\
\text { presidential campaign }(0.4) ; \\
\text { public segmentation model } \\
(0.4) ; \text { finding publics }(0.4) ; \\
\text { pragmatic cultural schema } \\
(0.4) ; \text { stakeholder relationship } \\
(0.4) ; \text { British public relation } \\
(0.4) ; \text { analysing public relations } \\
\text { communication strategies }(0.4) ; \\
\text { interactivity effect }(0.4) ;\end{array}$ & 2013 \\
\hline
\end{tabular}


Table 6: Keywords with the Strongest Citation Bursts

\begin{tabular}{|l|c|l|l|l|l|}
\hline Keywords & Year & Strength & Begin & End & $\mathbf{1 9 8 0 - 2 0 1 9}$ \\
\hline public relations & 1980 & 13.6206 & $\mathbf{2 0 0 3}$ & 2010 & \\
\hline model & 1980 & 7.6304 & $\mathbf{2 0 0 7}$ & 2014 & \\
\hline
\end{tabular}

Table 7: Top Ranked Cited Documents by Centrality (Cited in the Dataset of this Paper)

\begin{tabular}{|c|c|c|}
\hline Centrality & Year & Cited document \\
\hline 0.32 & 2011 & $\begin{array}{l}\text { Jeong-Nam Kim, } \\
\text { Strategic Thinking About Employee Communication Behaviour (ECB) in Public } \\
\text { Relations: Testing the Models of Megaphoning and Scouting Effects in Korea, } \\
\text { Journal of Public Relations Research, 23(3), 243-268. } \\
\text { DOI 10.1080/1062726X.2011.582204 }\end{array}$ \\
\hline 0.21 & 2014 & $\begin{array}{l}\text { Kim A. Johnston, } \\
\text { Public Relations and Engagements: Theoretical Imperatives of a Multi- } \\
\text { Dimensional Concept, } \\
\text { Journal of Public Relations Research, 26(5), 381-383. } \\
\text { DOI: } 10.1080 / 1062726 \text { X.2014.959863 }\end{array}$ \\
\hline 0.20 & 2014 & $\begin{array}{l}\text { Moonhee Cho, Tiffany Schweickart, \& Abigail Haase, } \\
\text { Public Engagement with Non Profit Organisations on Facebook, Public Relations } \\
\text { Review, 40(3), 565-567. } \\
\text { DOI 10.1016/j.pubrev.2014.01.008 }\end{array}$ \\
\hline 0.16 & 2011 & $\begin{array}{l}\text { Robert Banks, } \\
\text { A Resource Guide to Public Diplomacy Evaluation, } \\
\text { Figueroa Press, Los Angeles. }\end{array}$ \\
\hline 0.12 & 2006 & $\begin{array}{l}\text { Robert L. Heath, } \\
\text { Onward Into More Fog: Thoughts on Public Relations' Research Directions, } \\
\text { Journal of Public Relations Research, 18:2,93-114, } \\
\text { DOI: } 10.1207 / \text { s1532754xjprr1802 } 2\end{array}$ \\
\hline 0.10 & 2014 & $\begin{array}{l}\text { Maureen Taylor \& Michael L. Kent, } \\
\text { Dialogic Engagement: Clarifying Foundational Concepts, } \\
\text { Journal of Public Relations Research, 26:5, 384-398, } \\
\text { DOI: } 10.1080 / 1062726 \text { X.2014.956106 }\end{array}$ \\
\hline 0.09 & 2008 & $\begin{array}{l}\text { Nina Eyrich, Monica L Padman \& Kaye D. Sweetser, } \\
\text { PR practitioners' use of social media tools and communication technology, } \\
\text { Public Relations Review 34, 412-414 } \\
\text { DOI 10.1016/J.PUBREV.2008.09.010 }\end{array}$ \\
\hline 0.09 & 2011 & $\begin{array}{l}\text { Jeong-Nam Kim \& James E Grunig, } \\
\text { Problem Solving and Communicative Action:A Situational Theory of Problem } \\
\text { Solving, } \\
\text { Journal of Communication, } 61120-149 \\
\text { DOI } 10.1111 / \mathrm{J} .1460-2466.2010 .01529 . \mathrm{X}\end{array}$ \\
\hline 0.09 & 2011 & $\begin{array}{l}\text { Maureen Taylor, } \\
\text { Building Social Capital Through Rhetoric and Public Relations, } \\
\text { Management Communication Quarterly 25(3) 436-454, } \\
\text { DOI 10.1177/0893318911410286 }\end{array}$ \\
\hline 0.08 & 2014 & $\begin{array}{l}\text { Karen E. Mishra, L Boynton \& Aneil K Mishra, } \\
\text { Driving Employee Engagement: The Expanded Role of Internal Communications, } \\
\text { International Journal of Business Communication, 51(2) 183-202 } \\
\text { DOI 10.1177/2329488414525399 }\end{array}$ \\
\hline
\end{tabular}


Table 8: Frequency Values of Top Cited Documents (Cited in the Dataset of this Paper)

\begin{tabular}{|c|c|c|}
\hline Frequency & Year & Cited Document \\
\hline 13 & 2014 & $\begin{array}{l}\text { Maureen Taylor \& Michael L. Kent, } \\
\text { Dialogic Engagement: Clarifying Foundational Concepts, } \\
\text { Journal of Public Relations Research, 26:5, 384-398, } \\
\text { DOI: } 10.1080 / 1062726 \text { X.2014.956106 }\end{array}$ \\
\hline 13 & 2007 & $\begin{array}{l}\text { Patricia. A. Curtin \& Kenn T Gaither, } \\
\text { International Public Relations. SAGE Publications, Inc; }\end{array}$ \\
\hline 11 & 2011 & $\begin{array}{l}\text { Jacquie L'Etang \& Magda Pieczka, } \\
\text { Public relations as dialogic expertise? } \\
\text { Journal of Communication Management, } 15(2), 108-124 . \\
\text { doi.org/10.1108/13632541111126346 }\end{array}$ \\
\hline 11 & 2008 & $\begin{array}{l}\text { Nina Eyrich, Monica L. Padman \& Kaye D. Sweetser, } \\
\text { PR practitioners' use of social media tools and communication technology, } \\
\text { Public Relations Review 34, 412-414 } \\
\text { DOI 10.1016/J.PUBREV.2008.09.010 }\end{array}$ \\
\hline 10 & 2011 & $\begin{array}{l}\text { Jeong-Nam Kim \& James E. Grunig, } \\
\text { Problem Solving and Communicative Action:A Situational Theory of Problem } \\
\text { Solving, } \\
\text { Journal of Communication } 61120-149 \\
\text { DOI } 10.1111 / \text { J.1460-2466.2010.01529.X }\end{array}$ \\
\hline 10 & 2011 & $\begin{array}{l}\text { Jeong-Nam Kim, } \\
\text { Strategic Thinking About Employee Communication Behaviour (ECB) in Public } \\
\text { Relations: Testing the Models of Megaphoning and Scouting Effects in Korea, } \\
\text { Journal of Public Relations Research, 23(3), 243-268. } \\
\text { DOI 10.1080/1062726X.2011.582204 }\end{array}$ \\
\hline 9 & 2013 & $\begin{array}{l}\text { Michael L. Kent, } \\
\text { Using social media dialogically: Public relations role in reviving democracy } \\
\text { Public Relations Review, 39(4), 337-345 doi.org/10.1016/j.pubrev.2013.07.024 }\end{array}$ \\
\hline 9 & 2009 & $\begin{array}{l}\text { Krishnamurthy Sriramesh \&Dejan Vercic, } \\
\text { The Global Public Relations Handbook Theory, Research, and Practice, } \\
\text { Lawrence Erlbaum Associates, Publishers Mahwah, New Jersey London }\end{array}$ \\
\hline 8 & 2007 & $\begin{array}{l}\text { Eyun-Jung Ki \& Linda Childers Hon, } \\
\text { Testing the Linkages Among the Organization-Public Relationship and Attitude } \\
\text { and Behavioral Intentions, } \\
\text { Journal of Public Relations Research, 19:1, 1-23, } \\
\text { DOI: } 10.1080 / 10627260709336593\end{array}$ \\
\hline 8 & 2009 & $\begin{array}{l}\text { Richard D. Waters, Emily Burnett, Anna Lamm \& Jessica Lucas, } \\
\text { Engaging stakeholders through social networking: How nonprofit organizations } \\
\text { are using Facebook, } \\
\text { Public Relations Review, } 35(2), 102-106 . \\
\text { DOI 10.1016/J.PUBREV.2009.01.006 }\end{array}$ \\
\hline
\end{tabular}

Table 9: Authors with the Strongest Citation Bursts

\begin{tabular}{|l|c|c|c|c|l|}
\hline References & Year & Strength & Begin & End & $\mathbf{1 9 8 0 - 2 0 1 9}$ \\
\hline Grunig \& Grunig, 2002 & 2002 & 4.7893 & $\mathbf{2 0 0 7}$ & 2010 & \\
\hline Ki \& Hon, 2007 & 2007 & 3.9609 & $\mathbf{2 0 0 9}$ & 2014 & \\
\hline
\end{tabular}


Table 10: Summary of the Largest 5 Clusters of Trend Topic

\begin{tabular}{|c|c|c|c|c|c|c|}
\hline Cluster & Size & $\begin{array}{c}\text { Mean } \\
\text { Silhouette }\end{array}$ & $\begin{array}{l}\text { Label } \\
\text { (TFIDF) }\end{array}$ & $\begin{array}{l}\text { Label } \\
\text { (LLR) } \\
\text { p value }\end{array}$ & Label (MI) & $\begin{array}{c}\text { Average } \\
\text { Citation } \\
\text { Year }\end{array}$ \\
\hline 0 & 54 & 0.919 & $\begin{array}{l}\text { public } \\
\text { relations }\end{array}$ & $\begin{array}{c}\text { global flux } \\
(53.82,1.0 \mathrm{E}-4)\end{array}$ & $\begin{array}{c}\text { ethical framework (0.57); examining } \\
\text { linkage }(0.57) ; \text { peso media strategy } \\
\text { shift }(0.57) \text {; analyzing network }(0.57) ; \\
\text { communication expert }(0.57) ; \\
\text { presidential election }(0.57) \text {; leadership } \\
\text { performance }(0.57) ; \text { public relations } \\
\text { specialist }(0.57) ; \text { agenda building } \\
(0.57) ; \text { source classification }(0.57) ;\end{array}$ & 2005 \\
\hline 1 & 40 & 0.865 & $\begin{array}{l}\text { public } \\
\text { relations }\end{array}$ & $\begin{array}{c}\text { blog- } \\
\text { mediated crisis } \\
\text { communication } \\
\text { model }(68.12 \\
1.0 \mathrm{E}-4)\end{array}$ & $\begin{array}{c}\text { public relations practitioner }(0.23) ; \\
\text { social media domain }(0.23) ; \text { dual role } \\
(0.23) \text {; examining linkage }(0.23) ; \text { peso } \\
\text { media strategy shift }(0.23) \text {; analyzing } \\
\text { network }(0.23) ; \text { communication } \\
\text { expert }(0.23) \text {; presidential election } \\
(0.23) \text {; leadership performance }(0.23) ; \\
\text { public relations specialist }(0.23) ;\end{array}$ & 2009 \\
\hline 2 & 37 & 0.782 & Times & $\begin{array}{l}\text { stakeholder } \\
\text { relationship } \\
(49.23,1.0 \mathrm{E}-4)\end{array}$ & $\begin{array}{c}\text { communication expert }(0.35) ; \\
\text { interactive writing }(0.35) ; \\
\text { understanding dialogue }(0.35) ; \\
\text { examining linkage }(0.35) ; \text { peso } \\
\text { media strategy shift }(0.35) ; \text { analyzing } \\
\text { network }(0.35) ; \text { presidential election } \\
(0.35) ; \text { leadership performance }(0.35) ; \\
\text { public relations specialist }(0.35) ; \\
\text { agenda building }(0.35) ;\end{array}$ & 2011 \\
\hline 3 & 35 & 0.902 & $\begin{array}{l}\text { public } \\
\text { relations }\end{array}$ & $\begin{array}{c}\text { deliberative } \\
\text { system }(50.59, \\
1.0 \mathrm{E}-4)\end{array}$ & $\begin{array}{c}\text { reflective communication scrum } \\
(0.33) \text {; agile public relation }(0.33) ; \\
\text { examining linkage }(0.33) \text {; peso } \\
\text { media strategy shift }(0.33) \text {; analyzing } \\
\text { network }(0.33) \text {; communication } \\
\text { expert }(0.33) ; \text { presidential election } \\
(0.33) \text {; leadership performance }(0.33) ; \\
\text { public relations specialist }(0.33) ; \\
\text { agenda building }(0.33) ;\end{array}$ & 2012 \\
\hline 4 & 35 & 0.874 & $\begin{array}{l}\text { public } \\
\text { relations }\end{array}$ & $\begin{array}{c}\text { public relations } \\
\text { agencies }(51.39, \\
1.0 \mathrm{E}-4)\end{array}$ & $\begin{array}{c}\text { peso media strategy shift }(0.31) ; \\
\text { ethical dilemma }(0.31) \text {; examining } \\
\text { linkage }(0.31) \text {; analyzing network } \\
(0.31) \text {; communication expert }(0.31) ; \\
\text { presidential election }(0.31) \text {; leadership } \\
\text { performance }(0.31) \text {; public relations } \\
\text { specialist }(0.31) \text {; agenda building } \\
(0.31) \text {; source classification }(0.31) ;\end{array}$ & \\
\hline
\end{tabular}


Figure 1: Institution Collaboration Networks

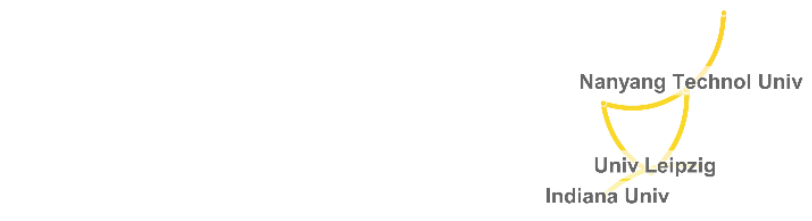

Univ South Carolina

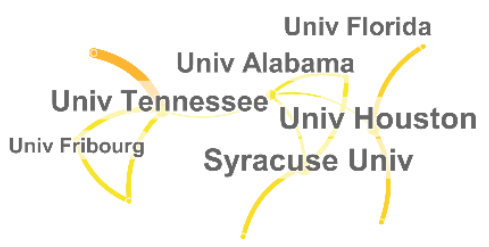

Univ Colorado

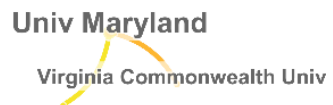

Virginia Commonwealth Univ

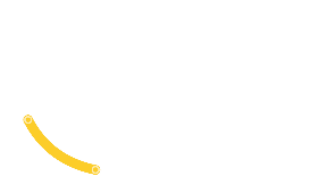

Univ Amsterdam

The network is composed of 53 nodes and 23 connections. The density is 0.015 .

Modularity value is Q:0.79 and mean silhouette value is 0.24 .

Figure 2: Country Collaboration Networks

SOUTH AFRICA

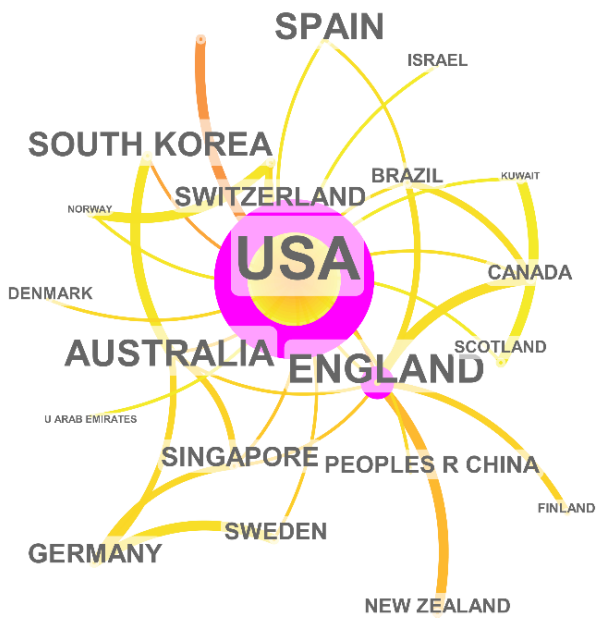

RUSSIA

The network is composed of 26 nodes and 33 connections. The density is 0.10 .

Modularity value is Q:0.41 and mean silhouette value is 0.43 . 
Figure 3: Keyword Network Analysis

strategic communication

corporate social responsibility

tatin:

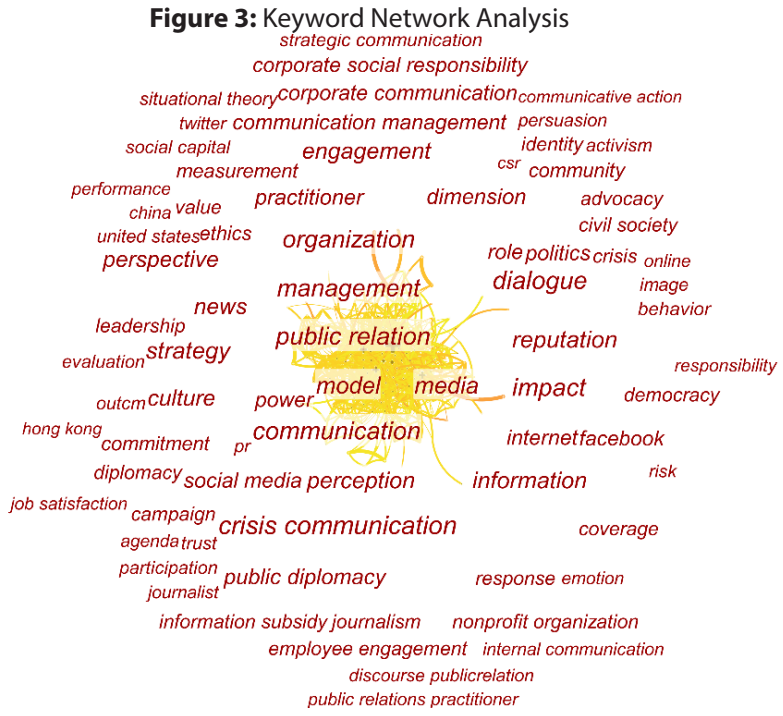

The network is composed of 182 nodes and 1009 connections. IT is divided into 7 clusters and the density is 0.06. Modularity value is $\mathrm{Q}: 0.35$ and mean silhouette value is 0.71 .

Figure 4: Co-citation Network Analysis

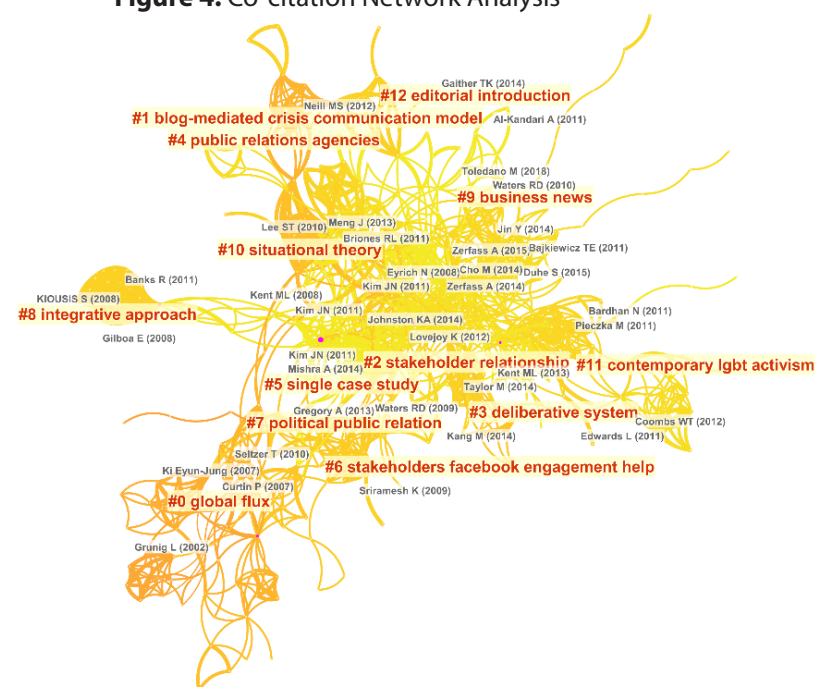

The network is composed of 475 nodes and 1680 connections. It is divided into 13 co-citation clusters and the density is 0.01 . Modularity value is $Q: 0.80$ and mean silhouette value is 0.40 